\title{
Contest of place as a basis for action in urban space. On the example of city squares in Częstochowa
}

\author{
Nina Sołkiewicz-Kos ${ }^{1}$
}

\begin{abstract}
:
Continuous urbanisation processes draw attention to the formal and functional solutions of urban spaces. They are a response to contemporary social and economic requirements. This paper presents examples of the evaluation of urban spaces. The activities concerning the context of the place are based on referring to the existing surroundings, its past and present, and are part of contemporary trends in the design of urban spaces in urban areas. Częstochowa is a city with a rich history and clear spatial structure. Its architecture and urban planning of particular historical, cultural and social value begs a thorough analysis of design activities presenting a vision of the future of these places.
\end{abstract}

\section{KEYWORDS:}

urban planning; architecture; revitalisation

\section{Introduction}

Continuous urbanisation processes draw attention to the formal and functional solutions of urban spaces. They are a response to contemporary social and economic requirements. The changing use of historical cultural space and the attempt to reconcile the architecture and function of new places is the basis for shaping a coherent urban space.

This paper presents examples of evaluations of urban spaces. Each of them is a response to the local programme offer and the context of cultural space. The activities concerning the context of the place are based on the reference to the existing environment, its past and present, and are part of the contemporary tendencies concerning the design of urban spaces in urban areas.

\section{Contextualism as a city-forming strategy}

Proper city formation strategies and tactics require interdisciplinary action and the creation of best solutions. Respect for the context of the place and its creative continuation is part of contemporary trends in urban space design in urban areas. This is particularly important for maintaining a good planning tradition.

Contextualism, as a strategy for city formation, was formulated at Cornell University in the early 1960s. It took Gestalt character psychology as its starting point, which was used to analyse the urban fabric. As a result of these analyses, requirements were identified for newly designed elements of the city. They concern both the architecture of the building and its place in the urban structure of the city. The whole assumption is to be a response to the contemporary needs of using cultural space.

1 Czestochowa University of Technology, Faculty of Civil Engineering, ul. Akademicka 3, 42-218 Częstochowa, e-mail: ninasołkiewiczkos@gmail.com, orcid id: 0000-0001-5477-3891 
The double Gestalt image of 'form - background' is an example of how the structure of the city functions. This arrangement, which can be read both ways - as solid or void, as black or white - is the key to a contextualist approach to urban space.

A model for recognising contextual activities can be the map of Rome drawn by G. Nolli (1748), where cubature (private) buildings were marked in grey, and public space remained white - these are streets, squares, courtyards, and the interiors of churches or public buildings (Fig. 1). The map shows private and public space and illustrates the relationship between them. Paying too much attention to objects or masses, whose main task is to create prestige rather than mechanisms of open use may disrupt the process of good continuity. Such actions lead to neglecting the surrounding space. Therefore a new strategy of city building based on contextual actions is to refer to the existing environment, its past and present [1].

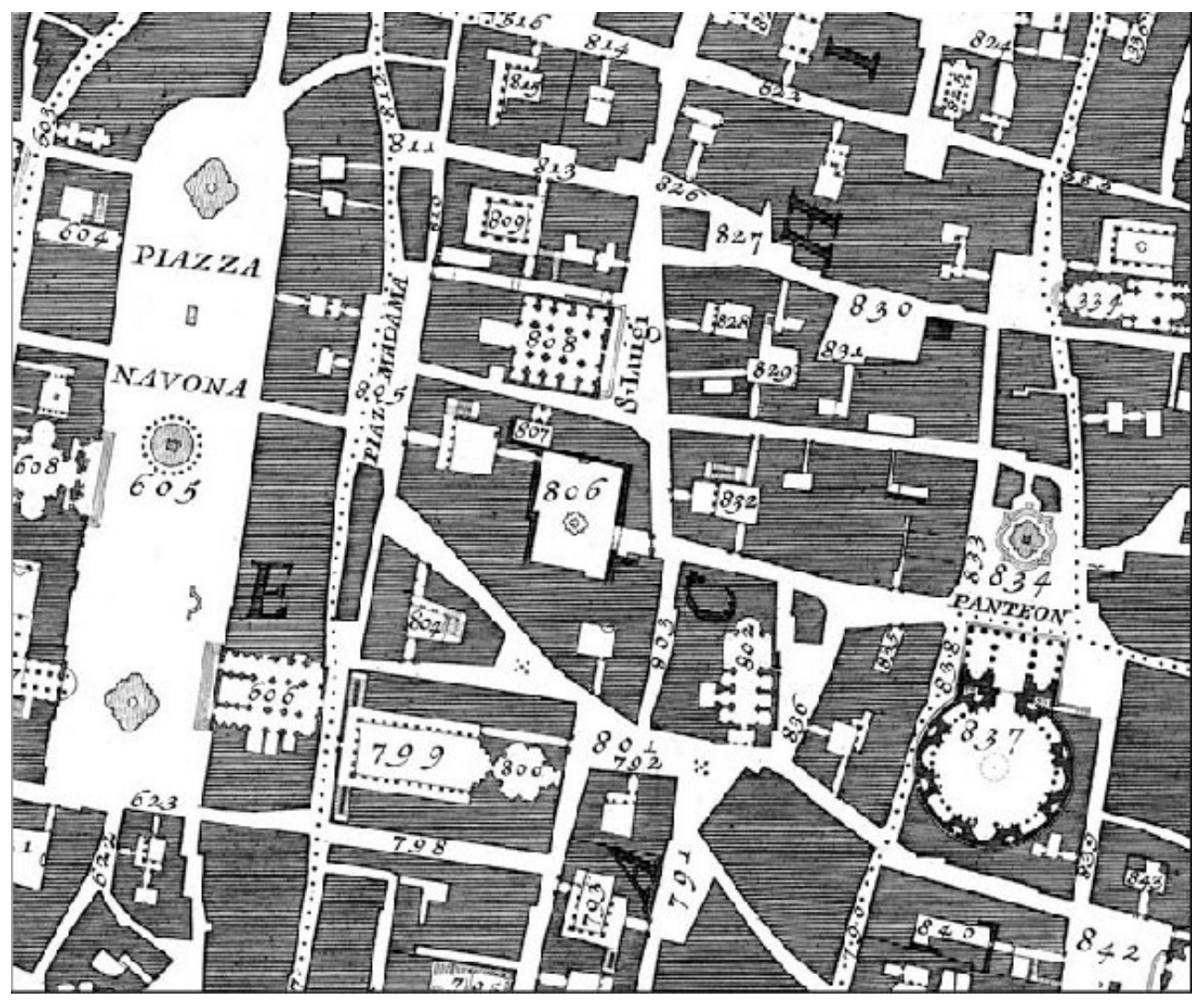

Fig. 1. Gianbattista Nolli: map of Rome, 1748 - detail (public domain)

\section{The space of the square in the context of the historical development of the city}

Częstochowa is a city with a rich history and clear spatial structure. The important place in the city is taken by its downtown areas. They constitute a space of particular aesthetic and functional values. Their way of development emphasises the importance of the city and is an example of the contemporary continuation of urban tradition.

In this article, the author presents the spaces of city squares, which belong to downtown areas. The architecture of these places and the urban context, with its special historical, cultural and social value, leads us to conduct a thorough analysis of design activities presenting a vision of the future of these places. 


\subsection{Design of the Biegański Square space}

The design of the space of Biegański Square is an example of an appropriate strategy and tactic of city formation. The analysis of the spatial structure of the city, the understanding of the importance of this space contributed to its modification. The solutions adopted constitute a consistent continuation of the previous urban assumptions. The design of the space of Biegański Square shows the interpretation possibilities of the historical urban assumptions of the city. Despite the passage of time, this arrangement allows for changes that meet the expectations of the urban community. At the same time, it preserves and sustains those elements of the urban structure of the city that constitute a continuation of the urban tradition [2].

The impulse for implementation works in the city centre areas were numerous competitions and debates organised by the local Częstochowa Branch of the Association of Polish Architects in cooperation with the Częstochowa City Council[3]. The aim of the competition tasks was to present solutions for selected public spaces. The subject of the competition, which included issues concerning the development of Biegański Square, concerned the dialogue between the street and the square. The winning entry (Pracownia Architektury "Forma" Sp z o.o., Blachownia), presenting the best functional-spatial solution for Biegański Square, created a legibly shaped urban space[4].

The space of the square seamlessly blends into the adjacent sections of N.M.P. Avenue. The other cultural structures surrounding the square are the historical buildings of the Town Hall and Odwach (from the south) and the park with St. Jacob's Church (from the north)[5]. The plate of the square distances the adjacent objects and enriches the space between them in a clear reference to the existing surroundings, its past and present. The space of the square, its scale and form distances and integrates the zones of sacrum and profanum allowing them to freely permeate and interact (Fig. 2).

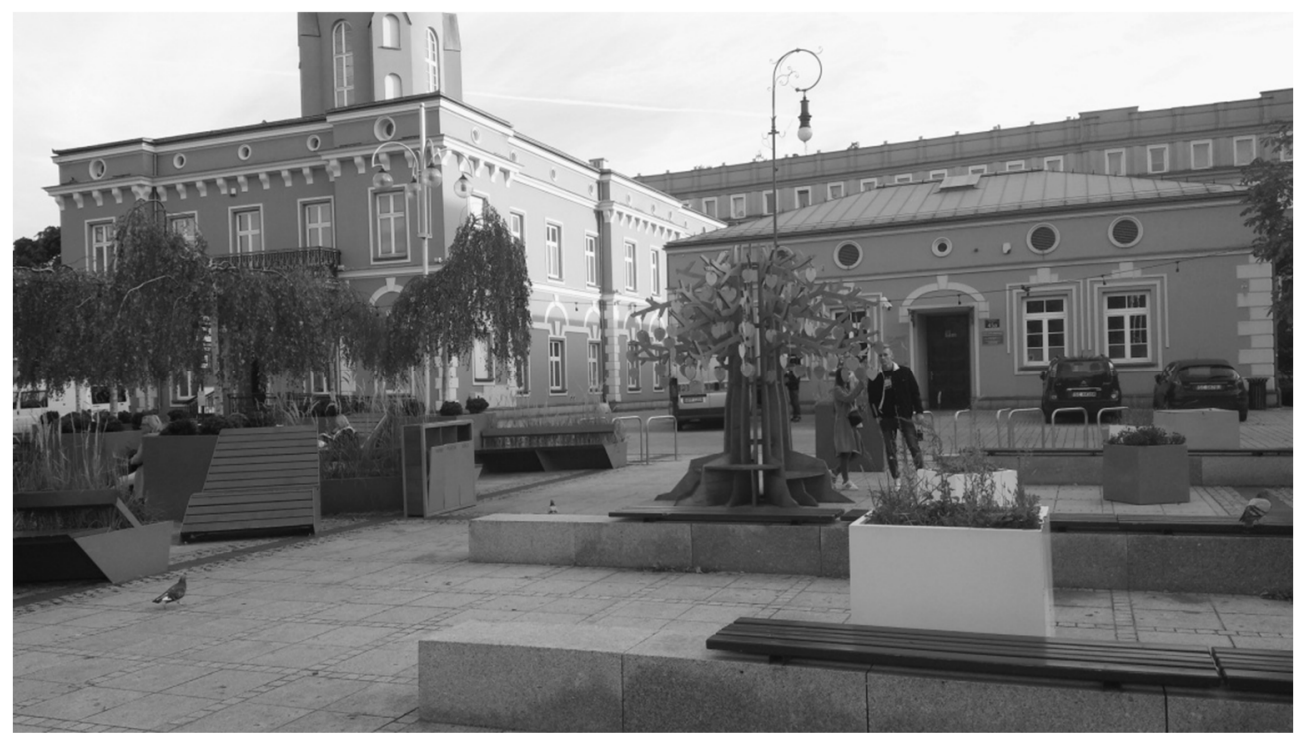

Fig. 2. Biegański Square, arrangement of the square with forms of small architecture, a place frequently visited by local community (photo: N. Solkiewicz-Kos)

The proposed solution of the square constitutes an integral element of N.M.P. Avenue, enriching and preserving the historical layout of the entire urban premise of the city. The design of the space of Biegański Square is an example of proper intervention in historical urban structures. The ongoing conceptual transformations related to this place, completely change the image of the city, while maintaining the relationship with tradition. 
The new cultural space has become a popular meeting place. The public accessibility and attractiveness of the new square space facilitates and encourages residents to interact with manifestations of cultural, artistic and social activities.

\subsection{Revitalisation of the Old Market area}

The revitalisation of the historical substance within the Old Market concerns the creation of a coherent urban space emphasising the historical, cultural and religious significance of this place. Actions taken in the area include the revitalisation of St Sigismund's Church with the monastery buildings as well as the restoration of building stock which is in a poor state of repair.

The second important area of activity is - revitalisation of the Old Market Square. The Old Market was the central point of the former city - Old Częstochowa. In the Middle Ages, numerous trade routes were concentrated here. In the period from the 15th to the beginning of the 19th century, there was a town hall (burnt in 1812). Noteworthy is the preserved layout of the northern and eastern frontage of the market, and the preserved buildings from the 17th, 18th and early 20th centuries [5].

Due to its importance and significance for the urban layout of the city, the spatial structure of the Old Market Square together with the St. Sigismund's Church complex and monastery buildings is a historically, culturally and socially significant area.

The first revitalisation works were undertaken at the end of the 20th century. The square was paved with red cobblestones. The outline of the medieval town hall and butcheries was paved with white and grey cobblestones. The slope of the square was profiled from the southern side in the form of disappearing steps inviting rest (Fig. 3).

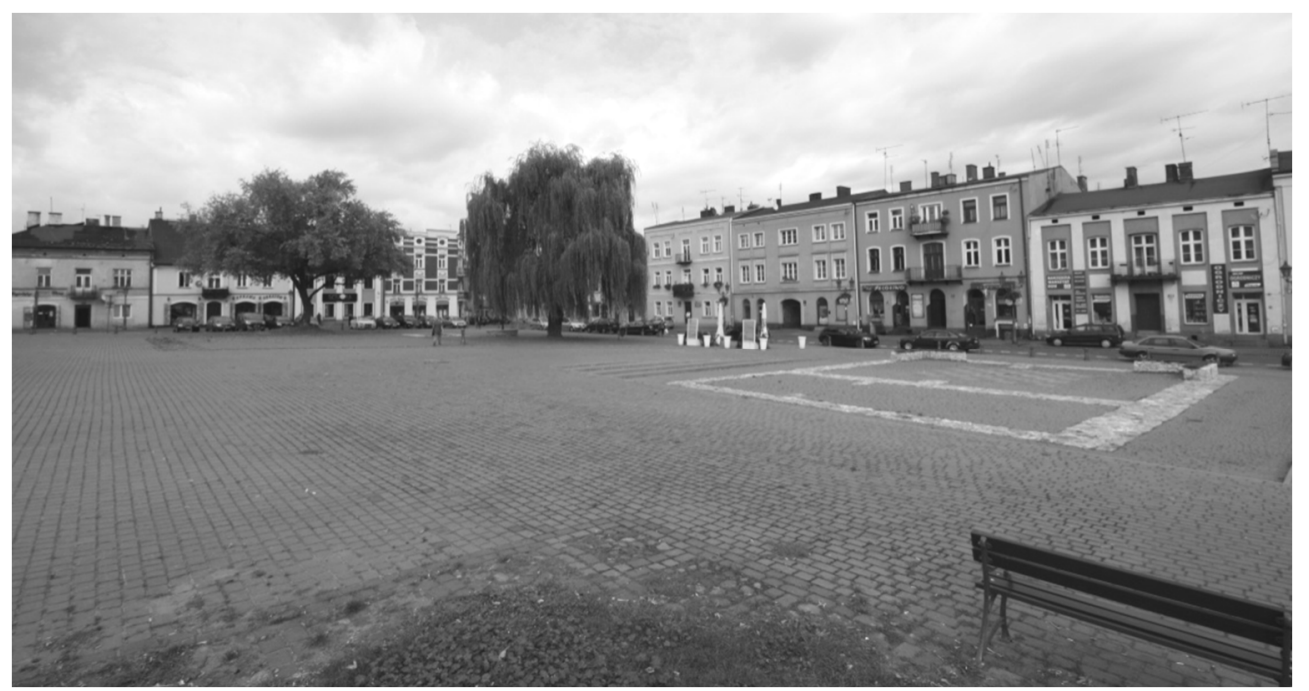

Fig. 3. Old Market, view of the square before the revitalisation works began, 2019 (photo: N. Solkiewicz-Kos)

The orderly surface of the Market Square space was supposed to attract tourists and residents of other districts to the Old Town. The lack of coherent relations between the Market Square space itself and the surrounding buildings of different architectural, urban and functional quality resulted in low interest in this part of the city[6]. The adopted solution did not meet expectations. Further competition activities were undertaken to search for the best solutions.

The solutions undertaken in the competition work with regard to the historic area of the Old Market mainly concerned the development of the market square. Design decisions concerning 
the function, form, technical and functional parameters, taking into account the remains of medieval buildings, are a form of incomplete revitalization. Renovation and replacement of the surface of the square, small architecture - they order the structure of this part of the city, but do not constitute a comprehensive analysis and classification of urban planning and architectural activities. Whether the replacement of one ordered surface with another will bring the expected result, it is yet to be confirmed.

The lack of reference to the frontages surrounding the Old Market (especially the most neglected one - the western one) and the lack of transport solutions connecting the Old Town zone with Aleje NMP leaves this sensitive area without a solution.

\section{Conclusions}

The presented examples of urban renewal concern interventions into the existing historic urban fabric. The formal and functional solutions of these spaces are surprisingly innovative. The activities undertaken are aimed at maintaining and enriching the valuable spatial structure of the city. The attempt to shape public spaces through competitions underlines the mature behaviour of the city authorities and their efforts to realise the best concepts. The context of the surroundings plays an important role in the process of shaping urban spaces. Its historical past in conjunction with contemporary cultural trends have the potential to create a public space of high utility value.

Searching for solutions for development of the "Old Town" area is a very difficult and complex task, which poses difficult questions to the designers concerning the essence of urbanity, ways of development of areas with very diverse functions and development methods

\section{References}

[1] Januszkiewicz K., Urban transformations - Back to history in Centre of the city - centre of Wrocław, Ossolineum, Wrocław 1986.

[2] Krier L., Architektura, Wybór czy przeznaczenie, Akady, Warszawa 2001.

[3] The Catalogue Published to the City of Czestochowa Order. SARP Contest No. 882 Concerning the Conception of Czestochowa Town Centre, Częstochowa, 1999/2000.

[4] "Komunikat SARP", January 2008.Competition for architectural conception of development of Daszyńskiego and Biegański Squares in Częstochowa together with connecting section of NMP Avenue, Drukarnia Tokawi. Warsaw 2008,40-45

[5] Braun J., Czestochowa, Urban-planning and Architecture, Warsaw 1979.

[6] Kevin L., Image of the city, Archivolta, Cracow 2011.

\section{Kontest miejsca jako podstawa działań w przestrzeni miejskiej. Na przykładzie przestrzeni placów miejskich w Częstochowie}

\section{STRESZCZENIE:}

Nieustanne procesy urbanizacji miast zwracają uwagę na rozwiązania formalne i funkcjonalne przestrzeni miejskich. Są one odpowiedzią na współczesne wymagania społeczne i gospodarcze. W artykule przedstawiono przykłady ewaluacji przestrzeni miejskich. Działania dotyczące kontekstu miejsca polegają na odwoływaniu się do zastanego otoczenia, jego przeszłości i teraźniejszości oraz wpisują się we współczesne tendencje dotyczące projektowania przestrzeni miejskich na terenach zurbanizowanych. Częstochowa to miasto o bogatej historii i czytelnej strukturze przestrzennej. Jego architektura i urbanistyka o szczególnej wartości historycznej, kulturowej i społecznej zobowiązuje do rzetelnej analizy działań projektowych prezentujących wizję przyszłości tych miejsc.

\section{SŁOWA KLUCZOWE:}

urbanistyka; architektura; rewitalizacja 